J. Lake Sci. (湖泊科学), 2018, 30(3): 628-639

DOI 10. 18307/2018. 0305

(c) 2018 by Journal of Lake Sciences

\title{
天津于桥水库沉积物磷赋存特征及其环境意义
}

\author{
江 雪 ${ }^{1,2}$, 文帅龙 ${ }^{1,3}$, 姚书春 ${ }^{1}$, 郑小兰 ${ }^{1,3}$, 康得军 $^{2}$, 钟继承 ${ }^{1 * *}$ \\ (1: 中国科学院南京地理与湖泊研究所湖泊与环境国家重点实验室,南京 210008) \\ (2:福州大学土木工程学院,福州 350000 ) \\ (3: 中国科学院大学,北京 100049)
}

\begin{abstract}
摘 要: 研究天津于桥水库沉积物中磷形态的空间分布特征和垂直分布特征对了解水源型水库富营养化现状及其过程 具有重要的现实意义. 利用抓斗式采泥器及柱状采泥器分别采集表层沉积物样品及柱状沉积物样品, 采用 Psenner 提出 的连续提取法对沉积物磷形态进行分级测定, 揭示整个水库沉积物各形态磷的空间分布特征以及不同区域垂直方向上 的分布规律. 结果表明:于桥水库表层沉积物总磷 ( TP) 含量为 $303.7 \sim 997.8 \mathrm{mg} / \mathrm{kg}$, 各形态磷含量大小顺序依次为: 钙结 合态磷 $(\mathrm{Ca}-\mathrm{P})>$ 铁结合态磷 $(\mathrm{Fe}-\mathrm{P})>$ 残渣态磷 $($ Res-P $)>$ 铝结合态磷 $(\mathrm{Al}-\mathrm{P})>$ 有机态磷 $($ Org-P $)>$ 可交换态磷 $($ Ex-P $)$. 表层 沉积物中 Fe-P、Al-P、Ca-P 与 TP 含量由东至西逐渐递减, 主要受到黎河河水夹带的外源性磷输人的影响; Res-P 含量由东 至西逐渐递增, 与活性磷的分布规律相反, 表明水库下游比上游的水质更好. 垂直分布上, 南部区域底层与表层沉积物相 差不大, 说明从 1960s 以来磷的沉积量就比较大; 西部区域沉积物中 Fe-P 和 Org-P 含量较高, 随深度的增加有明显降低的 趋势; 中心区域的各形态磷和 TP 含量均较低, 且随着深度增加逐渐降低, 现阶段沉积物中的磷以滞留为主, 释放潜力 较小.
\end{abstract}

关键词: 于桥水库;沉积物; 磷形态; 分布

\section{Environmental significance of phosphorus existing forms in the sediments of Yuqiao Res- ervoir in Tianjin}

JIANG Xue $^{1,2}$, WEN Shuailong ${ }^{1,3}$, YAO Shuchun ${ }^{1}$, ZHENG Xiaolan ${ }^{1,3}$, KANG Dejun ${ }^{2}$ \& ZHONG Jicheng ${ }^{1 * *}$

(1: State Key Laboratory of Lake Science and Environment, Nanjing Institute of Geography and Limnology, Chinese Academy of Sciences, Nanjing 210008, P.R.China)

(2: College of Civil Engineering, Fuzhou University, Fuzhou 350000, P.R.China)

(3: University of Chinese Academy of Sciences, Beijing 100049, P.R.China)

Abstract: It is of great significance to study the status of eutrophication and its process in water source reservoirs by analyzing the spatial and vertical distribution characteristics of phosphorus forms in the sediment of Yuqiao Reservoir in Tianjin. The samples of surface sediments and sediment cores were collected by grab-type sampler and column-type sampler, respectively, and the phosphorus forms of sediments were analyzed by continuous extraction method proposed by Psenner, in order to reveal the spatial distribution of various forms of phosphorus in the reservoir, as well as the distribution in the vertical direction of different regions. The results showed: The contents of total phosphorus in the surface sediments of Yuqiao Reservoir were 303.7-997.8 mg/kg, and the order of the mass fraction of phosphorus forms was: Ca-P $>$ Fe-P $>$ Res-P $>$ Al-P $>$ Org-P $>$ Ex-P. The Fe-P, Al-P, Ca-P and TP in the surface sediments gradually decreased from east to west, mainly affected by the input of exogenous phosphorus entrained by the Lihe River. The Res-P is gradually increasing from east to west, contrary to the distribution of active phosphorus, indicating that the water quality in the downstream of the reservoir is better than that in the upstream. For the vertical distribution, there is little difference between the bottom sediments and the surface sediments in the southern region, which indicates that the deposition amount of

* 国家自然科学基金项目 (41371457)、国家水体污染控制与治理科技重大专项(2013ZX07113001)和天津市水务局于桥 水库专项联合资助. 2017-07-30 收稿;2017-10-09 收修改稿. 江雪(1993 ), 女, 硕士研究生; E-mail: kssmail@ 163. com.

** 通信作者; E-mail: jczhong@ niglas.ac.cn. 
phosphorus is relatively large since the 1960s; and the Fe-P and Org-P contents in the western sediments are higher, and the trend is significantly reduced as the depth increases. The various forms of phosphorus and TP contents in the central area are almost the lowest, and gradually decrease with the depth, phosphorus in the sediments at this stage is mainly retained with small release potential.

Keywords: Yuqiao Reservoir; sediments; phosphorus forms; distribution

磷是水生生态系统中重要的营养限制因子, 同时也是湖泊水库发生富营养化的重要指标之一 ${ }^{[1]}$, 现阶 段关于磷在水体中赋存特征的研究, 研究者关注的不单单是磷在沉积物中的总量, 总磷通常只能反映磷在 沉积物中的累积程度, 并不能判断其生物稳定性以及释放风险 ${ }^{[2]}$, 因此越来越多的研究目标转向磷在沉积 物中的赋存形态 ${ }^{[3]}$. 深人分析磷在沉积物中的不同形态, 进而揭示沉积物磷的释放风险及来源, 对于水体环 境质量的评估具有重要意义. 沉积物中磷的形态决定了沉积物中能参与沉积物一水界面交换及生物可利用 磷的含量, 其地球化学形态是判别沉积物中磷的迁移能力和生态效应的重要参数 ${ }^{[4-6]}$. 通过测定磷在表层沉 积物中磷的赋存形态及其含量, 来研究沉积物向上覆水体释放和吸附磷营养盐的循环过程和发生机制, 同 时通过研究表层沉积物中磷的空间分布规律来判断外源性输人的高低. 磷在沉积物不同深度的垂直分布特 征与湖泊水库内源负荷有直接的关联, 不同赋存形态的磷对于内源磷的释放有不同的贡献, 导致不同赋存 形态的磷对于湖泊水库发生富营养化所起的作用不同 ${ }^{[7-8]}$, 通过比较磷在沉积物中的赋存形态和含量, 探求 磷在沉积物中的行为特征和分布规律, 用以描述它的释放风险. 因此, 研究不同空间分布和垂直分布的沉积 物磷形态的含量及其变化,可以加深对沉积物磷形态转化机制及污染来源的理解.

于桥水库是国家重点大型水库之一, 是引㴒人津工程的重要调蓄水库, 同时也是天津市重要的的饮用 水源地. 近 20 年来频繁、过度的人类活动已经导致水体污染和水质恶化, 尤其是受上游调水水库潘家口、大 黑汀水库及人库河道水质的影响, 近年来已开始出现藻类水华, 水库水体的自净能力已经无法维持原本的 生态系统平衡 ${ }^{[9]}$, 因此对于桥水库的富营养化状态、进程进行研究及开展后续生态修复工作迫在眉睫. 现阶 段针对内陆淡水湖泊和河流的磷形态研究较多, 对于水源型水库的研究较少. 迄今为止对于于桥水库的水 体污染、富营养化的研究主要集中在对库区流域生态环境保护和浮游生物群落特征的分析 ${ }^{[10-11]}$, 而对水库 内源负荷的研究尚未涉及, 尤其对于桥水库沉积物中磷及其赋存形态的研究更是鲜见报道. 因此, 本文对于 桥水库磷及其赋存形态进行研究, 了解水库沉积物中磷的垂直分布和空间分布特征, 掌握于桥水库沉积物 中磷的分布规律, 分析内源释放能力及风险, 并结合水库周围日益增加的外源性污染的输人进行综合评价, 为防治水体富营养化和合理保护于桥水库提供理论依据.

\section{1 材料与方法}

\section{1 研究区域概况}

于桥水库 $\left(40^{\circ} 00^{\prime} \sim 40^{\circ} 04^{\prime} \mathrm{N}, 117^{\circ} 26^{\prime} \sim 117^{\circ} 37^{\prime} \mathrm{E}\right)$ 位于天津市北部的蓟县城东、翠屏山北部, 是天津市重 要的饮用水源地, 是一座典型的山谷与平原过渡的水库. 总流域面积为 $2060 \mathrm{~km}^{2}$, 年平均降水量为 $735 \mathrm{~mm}$. 在于桥水库的东面有 3 条主要人库河流, 分别为沙河、淋河和黎河, 沙河河水通过注人黎河间接进人水库; 在西面建有全长 $2222 \mathrm{~m}$ 的拦河大坝, 对水库进行水量的调控, 兴利库容的水位为 $21.06 \mathrm{~m}$, 水库下游是人口 众多的蓟县城区. 滦水是于桥水库的主要水源, 由潘家口水库放水, 沿滦河人大黑汀水库调节, 再沿黎河流 人于桥水库. 由于水产养殖, 近年来大黑汀水库底部水体厌氧, 大量可溶性磷随调水进人于桥水库.

\section{2 样品采集及前期处理}

于 2016 年 6 月下旬对于桥水库进行采样,其中采样点 S1 位于水库下游拦河大坝前, 西面是蓟县城区; 采样点 S2 和 S4 位于北部区域, 其北面为大片密集的村庄和农田; 采样点 S3 和 S6 位于水库南面, 靠近翠屏 山, 此处原来有几百户村庄, 由于政府的拆迁工作, 现在附近有零星居民居住; 采样点 S5 位于水库中心区 域; 采样点 S7、S8 和 S9 分别位于黎河人库河口、淋河人库河口和黎河河道(图 1). 表层沉积物样品用彼得森 采样器在采样点 $\mathrm{S} 1 \sim \mathrm{S} 6$ 采集; 柱状沉积物样品用柱状采样器在采样点 $\mathrm{S} 1 \sim \mathrm{S} 7$ 采集. 采样点的经纬度由 GPS 确定, 每个采样点均采集 3 个平行样. 在每个采样点采集 $0.5 \mathrm{~m}$ 以下上覆水样 $500 \mathrm{ml}$. 柱状沉积物样品以 5 $\mathrm{cm}$ 间隔进行分样. 采集的水样及表层沉积物样品用约 $4^{\circ} \mathrm{C}$ 冷藏箱保存, 采样结束后尽快送至中国科学院南 
京地理与湖泊研究所湖泊与环境国家重点实验室分析测定.

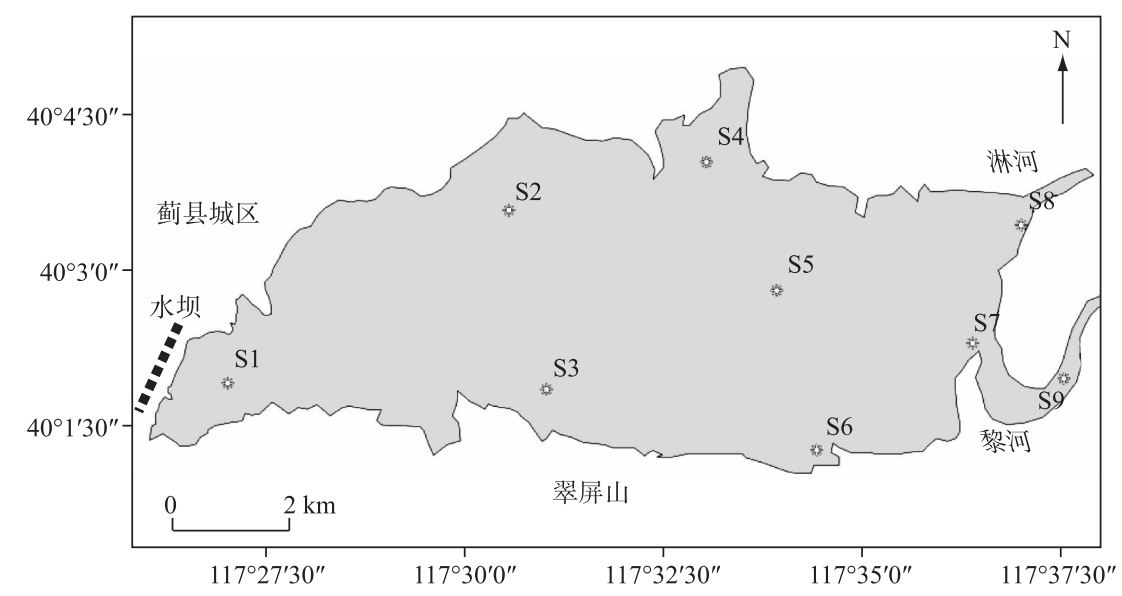

图 1 于桥水库采样点分布

Fig.1 Distribution of sampling sites in Yuqiao Reservoir

\section{3 样品测定方法}

上覆水溶解氧 ( DO )、 $\mathrm{pH}$ 、氧化还原电位 ( Eh) 等基础水质指标采用便携式多参数水质分析仪 ( YSI professional plus, 维赛仪器公司, 美国) 现场测定. 上覆水总磷 (TP) 和总氮 (TN) 浓度采用碱性过硫酸钾消解紫 外分光光度法测定, 沉积物 TP 含量采用过硫酸钾一钿锑抗分光光度法测定, 上覆水溶解性活性磷 (SRP) 浓 度和沉积物各形态磷含量采用钿锑抗分光光度法测定 ${ }^{[12]}$. 沉积物磷形态的分析方法采用国际上应用较为 广泛的 Psenner 连续提取法来测定 ${ }^{[13]}$, 具体步骤如图 2 所示, 在样品分析的过程中均设置平行样品、空白对 照及标准物质进行质量控制. 于桥水库沉积物中磷主要包括可交换态磷 ( Ex-P)、铁结合态磷 ( Fe-P)、铝结合 态磷 ( Al-P)、有机态磷 ( Org-P)、钙结合态磷 ( Ca-P) 和残渣态磷 (Res-P) 6 种形态.

为揭示于桥水库磷输人的历史过程, 在于桥水库中心位置采集沉积物柱样进行测年分析, 沉积物年代

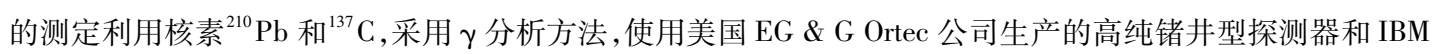
微机构成的 $16 \mathrm{~K}$ 多道分析器所组成的 $\gamma$ 谱分析系统. ${ }^{137} \mathrm{Cs}$ 和 ${ }^{226} \mathrm{Ra}$ 标准样品由中国原子能研究院提供; ${ }^{210} \mathrm{~Pb}$ 标准样品由英国利物浦大学提供.

\section{4 数据处理}

所有实验数据使用 Excel 2003 进行整理,使用 Origin 8.0 和 ArcGIS 10.2 软件制图.

\section{2 结果与讨论}

\section{1 上覆水体理化性质基本特征}

从表 1 可知, 于桥水库上覆水 TP 浓度介于 $0.189 \sim 0.403 \mathrm{mg} / \mathrm{L}$, 参考我国《地表水环境质量标准》( GB $3838-2002)$, 水库上覆水 $\mathrm{TP}$ 浓度介于 $\mathrm{IV}(0.1 \mathrm{mg} / \mathrm{L} \leqslant \mathrm{TP} \leqslant 0.2 \mathrm{mg} / \mathrm{L}) \sim \mathrm{V}(\mathrm{TP}>0.2 \mathrm{mg} / \mathrm{L})$ 类水平之间, $\mathrm{TN}$ 浓度介于 $\mathrm{IV}(1.5 \mathrm{mg} / \mathrm{L} \leqslant \mathrm{TN} \leqslant 2.0 \mathrm{mg} / \mathrm{L}) \sim \mathrm{V}(\mathrm{TN}>2.0 \mathrm{mg} / \mathrm{L})$ 类水平之间, $\mathrm{SRP}$ 浓度在 $0.028 \sim 0.136 \mathrm{mg} / \mathrm{L}$ 之 间, 比太湖 ${ }^{[5]}$ 、滇池 ${ }^{[3]}$ 、丹江口水库 ${ }^{[2]}$ 等都要高. 水库水体中 $\mathrm{N} 、 \mathrm{P}$ 浓度能够在一定程度上反映水质的基本状 况. 通常来说, 上覆水体中 N $\mathrm{P}$ 浓度会受到沿岸居民生产生活、人库河流等外源性输人与沉积物内源吸附和 释放的共同影响, 在一定的时间和空间范围内会达到一个相对稳定的动态平衡 ${ }^{[14]}$. 于桥水库 TP 浓度相对 于水源性水库来说还是较高的, 基本超过 $0.2 \mathrm{mg} / \mathrm{L}$, 但在空间分布上存在差异, 上覆水 $\mathrm{TP}$ 浓度最低出现在 水库的中间点位 S5, 水库中心区域的 TP 浓度均小于周围点位, 水库中心距离岸边较远, 因而受到的影响较 低, 说明上覆水 TP 浓度的增加主要受到外源性输人的影响. 上覆水 TP 浓度最高值主要集中在水库西部坝 前 $\mathrm{S} 1$ 点位以及北部 $\mathrm{S} 2$ 和 S4 两个点位, 水库北部城镇人口众多, 伴随而来的生活污水排放加剧导致较高营 


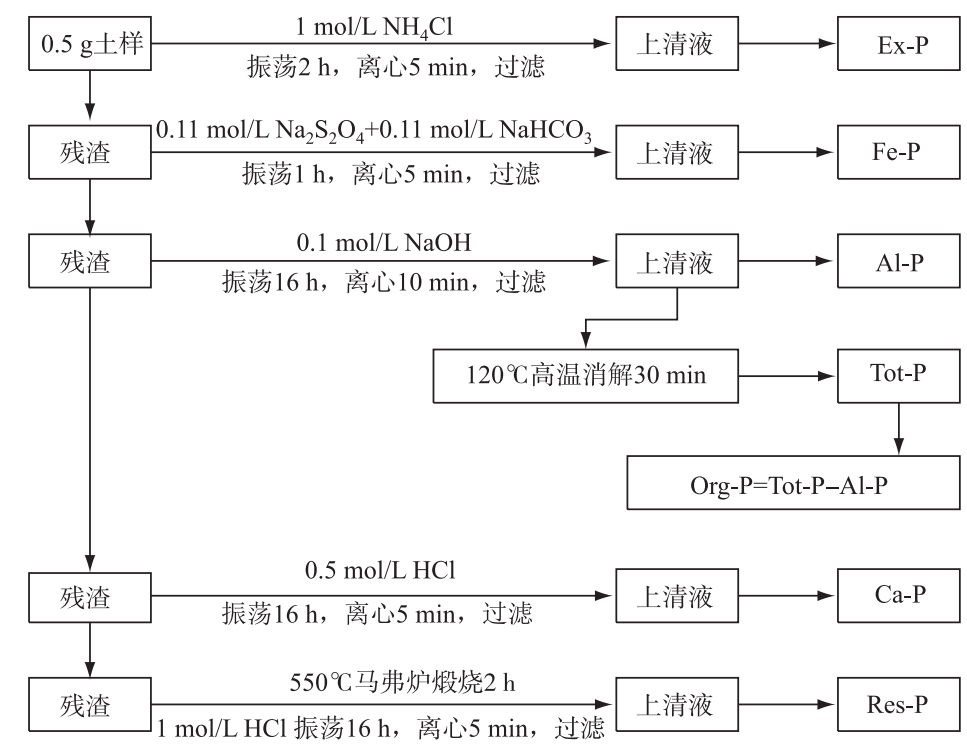

图 2 沉积物磷形态连续提取方法

Fig. 2 Sequential extractable method of phosphorusform in sediments

养盐的输人, 由此说明在所有外源性输人中, 人类活动是于桥水库上覆水体中 TP 浓度增加的重要原因. 在 藻类水华分布上, 由于采样时间为夏季, 本文虽然没有对水柱叶绿素浓度进行分析, 但可以观察到藻类水华 的发生, 在空间分布上总体来说藻密度东半库区要高于西半库区. 藻密度最高的区域为淋河河口及相邻的 峰山南库区, 该区域居住人口较多,农村生活污水的排放导致该区域水柱及底泥中营养盐含量偏高.

表 1 于桥水库上覆水理化性质

Tab.1 Physicochemical properties of the overlying waters in Yuqiao Reservoir

\begin{tabular}{ccccccc}
\hline 点位 & $\mathrm{TN} /(\mathrm{mg} / \mathrm{L})$ & $\mathrm{TP} /(\mathrm{mg} / \mathrm{L})$ & $\mathrm{SRP} /(\mathrm{mg} / \mathrm{L})$ & $\mathrm{Eh} / \mathrm{mV}$ & $\mathrm{pH}$ & 水深 $/ \mathrm{m}$ \\
\hline $\mathrm{S} 1$ & $4.107 \pm 0.054$ & $0.343 \pm 0.072$ & $0.062 \pm 0.015$ & 9.9 & 10.06 & 9.18 \\
$\mathrm{~S} 2$ & $2.573 \pm 0.047$ & $0.342 \pm 0.043$ & $0.028 \pm 0.014$ & 141.4 & 9.11 & 3.63 \\
S3 & $1.985 \pm 0.049$ & $0.192 \pm 0.052$ & $0.068 \pm 0.005$ & 56.1 & 9.35 & 4.36 \\
S4 & $3.836 \pm 0.075$ & $0.403 \pm 0.064$ & $0.040 \pm 0.008$ & 133.9 & 10.16 & 2.45 \\
S5 & $2.559 \pm 0.027$ & $0.189 \pm 0.042$ & $0.027 \pm 0.008$ & 101.2 & 9.40 & 4.60 \\
S6 & $1.841 \pm 0.047$ & $0.193 \pm 0.061$ & $0.039 \pm 0.007$ & 138.5 & 9.17 & 1.97 \\
S7 & $2.142 \pm 0.068$ & $0.248 \pm 0.097$ & $0.136 \pm 0.011$ & 141.5 & 9.35 & 4.73 \\
\hline
\end{tabular}

\section{2 沉积物磷形态的空间分布特征}

于桥水库各采样点表层沉积物的 TP 含量为 $303.7 \sim 997.8 \mathrm{mg} / \mathrm{kg}$, 平均值为 $594.6 \mathrm{mg} / \mathrm{kg}$. 根据 TP 含量 可以判断湖泊水库沉积物的污染水平 ${ }^{[15]}$ : 安全水平 ( $\mathrm{TP} \leqslant 600 \mathrm{mg} / \mathrm{kg}$ ); 中等水平 $(600 \mathrm{mg} / \mathrm{kg}<\mathrm{TP} \leqslant 2000 \mathrm{mg} /$ $\mathrm{kg}$ ) ; 高富营养化水平 ( TP $>2000 \mathrm{mg} / \mathrm{kg}$ ). 我国各地沉积物 TP 的分布情况不一致, 比如太湖沉积物 TP 含量为 $177.1 \sim 1325.8 \mathrm{mg} / \mathrm{kg}^{[16]}$; 滇池沉积物 TP 含量为 $1596.2 \sim 5558.5 \mathrm{mg} / \mathrm{kg}^{[17]}$; 三峡水库沉积物 TP 含量为 $390 \sim 810$ $\mathrm{mg} / \mathrm{kg}^{[18]}$. 于桥水库表层沉积物 TP 含量处于中低等水平, 其分布具有明显的空间差异性, 库区中心区域最 低, 而黎河人库口处最高, 可达 869.6 997.8 mg/ kg, 为库区中心区域的 $2.7 \sim 3.3$ 倍左右 (图 3). 本研究测得 潘家口水库沉积物 TP 含量为 $843.9 \sim 1022.9 \mathrm{mg} / \mathrm{kg}$, 大黑汀水库沉积物 TP 含量为 $1039.5 \sim 3149.6 \mathrm{mg} / \mathrm{kg}$, 黎 河河道沉积物 TP 含量为 $997.8 \sim 3833.1 \mathrm{mg} / \mathrm{kg}$, 另外上游潘家口水库及大黑汀水库为过度养殖水体, 水质及 底质较差, 在于桥水库调水期间, 黎河河水成为于桥水库的主要输人水源, 河水夹带大量的营养盐进人水 


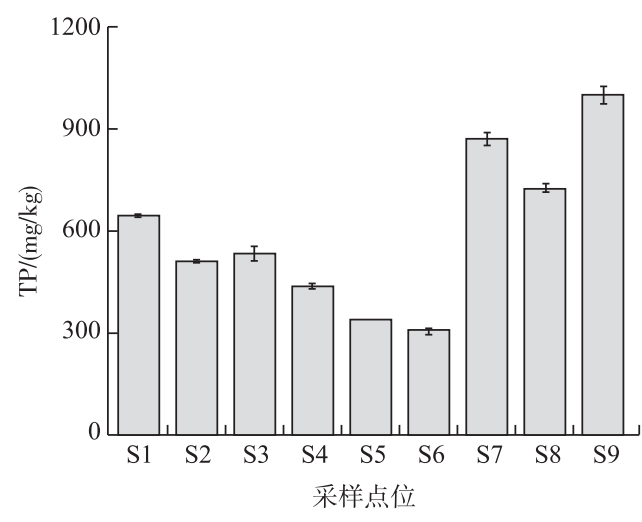

图 3 于桥水库表层沉积物中总磷含量及空间分布

Fig.3 Spatial distribution of total phosphorus in the surface sediments of Yuqiao Reservoir

中无机磷与有机磷含量几乎各占一半 ${ }^{[2]}$.
库, 同时河流两岸有大片果园和树木, 所施肥料和各种 生物残体会通过地表径流和地下径流汇人河流和水库 之中, 此处潜在生态危害性较大 ${ }^{[19]}$. 水库下游的拦河大 坝阻挡水流正常流出, 悬浮物包括泥沙及藻类颗粒中所 含营养物质在此处停留,常年不断累积使得 TP 含量略 高. 库区中心区域受到水动力作用不明显, 对沉积物的 扰动小, 沉积物一水界面之间的物质交换作用和扩散作 用缓慢,水质水量相对来说较为稳定,沉积物 TP 含量略 低. 因此, TP 的空间分布对于所处空间的环境条件变化 较为敏感.

于桥水库表层沉积物中各形态磷含量大小顺序依次 为: $\mathrm{Ca}-\mathrm{P}>\mathrm{Fe}-\mathrm{P}>\mathrm{Res}-\mathrm{P}>\mathrm{Al}-\mathrm{P}>\mathrm{Org}-\mathrm{P}>\mathrm{Ex}-\mathrm{P}$ (表 2). 由于不 同的湖泊和水库具有不同的地域、气候、植被和人文等环 境特征,并非所有湖泊水库沉积物中磷形态赋存特征都 是如此, 例如:太湖沉积物中 Al-P 含量高于 Fe- $\mathrm{P}^{[20]}$, 鄱阳 湖沉积物以 $\mathrm{Fe}-\mathrm{P}$ 为最主要的赋存形态 ${ }^{[21]}$, 丹江口水库

表 2 于桥水库表层沉积物中各形态磷含量

Tab.2 Contents of various forms of phosphorus in the surface sediments of the Yuqiao Reservoir

\begin{tabular}{cccccccc}
\hline 指标 & Ex-P & Fe-P & Al-P & Org-P & Ca-P & Res-P & TP \\
\hline 最大值 $/(\mathrm{mg} / \mathrm{kg})$ & 27.1 & 332.1 & 159.0 & 92.2 & 352.6 & 187.8 & 997.8 \\
最小值 $/(\mathrm{mg} / \mathrm{kg})$ & 0.8 & 75.3 & 12.3 & 28.1 & 126.1 & 38.9 & 303.7 \\
平均值 $/(\mathrm{mg} / \mathrm{kg})$ & 13.3 & 161.8 & 53.6 & 60.2 & 213.9 & 101.4 & 594.6 \\
标准偏差 & 8.6 & 87.8 & 51.5 & 21.4 & 74.2 & 49.4 & 222.2 \\
变异系数 $/ \%$ & 64.3 & 54.3 & 96.2 & 35.6 & 34.7 & 48.7 & 37.4 \\
\hline
\end{tabular}

Ex-P 通常是指吸附在沉积物矿物颗粒中的结构较为松散型的弱结合态磷, 于桥水库沉积物中 Ex-P 含 量为 $0.8 \sim 27.1 \mathrm{mg} / \mathrm{kg}$, 仅占 TP 的 $0.1 \% \sim 5.6 \%$, 在所有形态中含量最低. Ex-P 在沉积物一水界面很活跃, 很容 易与沉积物间隙水中的溶解态磷发生交换作用或者迁移进人上覆水体, 从而影响上覆水的磷浓度. Ex-P 的 空间分布呈现由南至北逐渐递增、东部人库河口高于库区的趋势. 有研究表明 ${ }^{[22]}$, 沉积物颗粒越小、比表面 积越大, 沉积物对 Ex-P 的吸附能力就越强, Ex-P 含量就会越高, 然而生活污水的排放与沉积物颗粒大小的 关系最为密切, 人类活动越频繁造成生活污水排放量越大, 使得附近的沉积物颗粒越细. 于桥水库北面为人 口众多的穿芳峪乡和马伸桥镇, 开挖了一条明渠直接进人水库之中, 污废水过度排放或者生活垃圾不经过 处理就直接进人水库等问题导致水体污染, 因此沉积物中 Ex-P 含量呈现由南向北逐渐递增的趋势, 所以需 要控制于桥水库北面居民生活污水的排放,避免水体污染.

$\mathrm{Fe}-\mathrm{P}$ 主要是指以各种不同形式与 Fe、Mn 化合物结合的磷. Ex-P、Fe-P 和 Al-P 同为潜在活性磷, 在溶解 氧变化、水体扰动作用不均的情况下, 潜在活性磷就会释放, 增加水体磷浓度. 于桥水库沉积物潜在活性磷 中 Fe-P 含量最高, 在释放过程中对上覆水体中磷浓度的影响最大 ${ }^{[23]}$, 导致内源磷的形态分布显著改变, 因 此 Fe-P 是对湖泊水库富营养化贡献最大的一种磷形态 ${ }^{[24]}$. 于桥水库沉积物中 Fe-P 含量的分布具有明显的 空间差异性(图 4), 人库河口处 Fe-P 大量富集, 远高于库区. 在人库河口处 Fe-P 含量最高可达 $332.1 \mathrm{mg} /$ $\mathrm{kg}$, 人库河口处 Fe-P 含量高的原因很可能是黎河上游在本世纪前 10 年大量开采铁矿山, 磁法选矿, 产生大 量细小的铁矿砂, 排放到了黎河, 随着调水进人于桥水库. 这些颗粒物到达人库河口时, 受到的水动力作用 变小, 容易在此处发生沉降, 粉砂岩中含有丰富的 $\mathrm{Fe} 、 \mathrm{Mn}$ 氧化物, 在水流冲刷和重力作用下的颗粒物与水体 中磷酸根离子充分接触和碰撞, $\mathrm{Fe} 、 \mathrm{Mn}$ 金属氧化物之间的化学键断裂, 形成 $\mathrm{Fe} 、 \mathrm{Mn}$ 金属离子与磷酸根离子 
相结合的弱吸附态磷, 进而被沉积物捕捉在固相表面, Fe-P 在沉积物一上覆水界面非常活跃, 最能体现沉积 物中磷的生物稳定性.

Al-P 是指在沉积物中铝与其氧化物或者氢氧化物相结合的磷. 于桥水库沉积物中 Al-P 的空间分布特 征和 Fe-P 大体相同 (图 4). Al-P 也是潜在活性磷, 同样能够释放至上覆水体中被生物所利用, 也能够转化 成 Ca-P 被沉积物固定, 但是沉积物中 Al-P 含量的变化幅度很小, 在各种形态磷中的转化不明显 ${ }^{[25]}$, 因此 Al-P 比 Fe-P 更为稳定. 沉积物中 Al-P 含量高低具有重要意义一一释放进人上覆水体中的生物可利用磷主 要来自 Al-P ${ }^{[26]}$, 因此, 沉积物中的 Al-P 可以用来评估生物可利用磷的高低 ${ }^{[27-28]}$, 于桥水库沉积物中 Al-P 含 量不高, 平均含量为 $53.6 \mathrm{mg} / \mathrm{kg}$, 仅占 TP 的 $2.4 \% \sim 13.5 \%$, 说明沉积物中生物可利用磷含量较低, 于桥水库 作为水源型水库, 上覆水水质比一般浅水湖泊好, 藻类、浮游动物等相对较少, 各种生物生长增殖所需要的 磷就更少.

Org-P 被认为是有条件的易释放磷, 只有部分 Org-P 具有活性, 能够被微生物降解成小分子物质以提供 自身的新陈代谢, 另一部分为不可降解的排泄物. 于桥水库沉积物中 Org-P 含量较低,空间分布较为平均, 库区中心稍低, 东、西部区域稍高 (图 4). 水草残渣、藻类和农业面源污染 ${ }^{[29]}$ 对沉积物中的 Org-P 都有贡献, 水库东部的 Org-P 主要是外源输人, 人库支流沙河和调水水源大黑汀水库的网箱养鱼现象严重, 上游的饵料 残渣沉淀导致水库东部河口区域 Org-P 含量较高; 水库西部 Org-P 含量较高, 主要来源是水草残渣和藻类沉 淀,生物的利用转化应当比外源多, 同时下游有大片农田和耕地,农业面源污染也有一定的贡献, 雨季来临 将无机和有机的肥料输人水库,导致水库沉积物中 Org-P 含量升高,并向库区中心蔓延,因此水库东、西部沉 积物中 Org-P 含量比库区高.

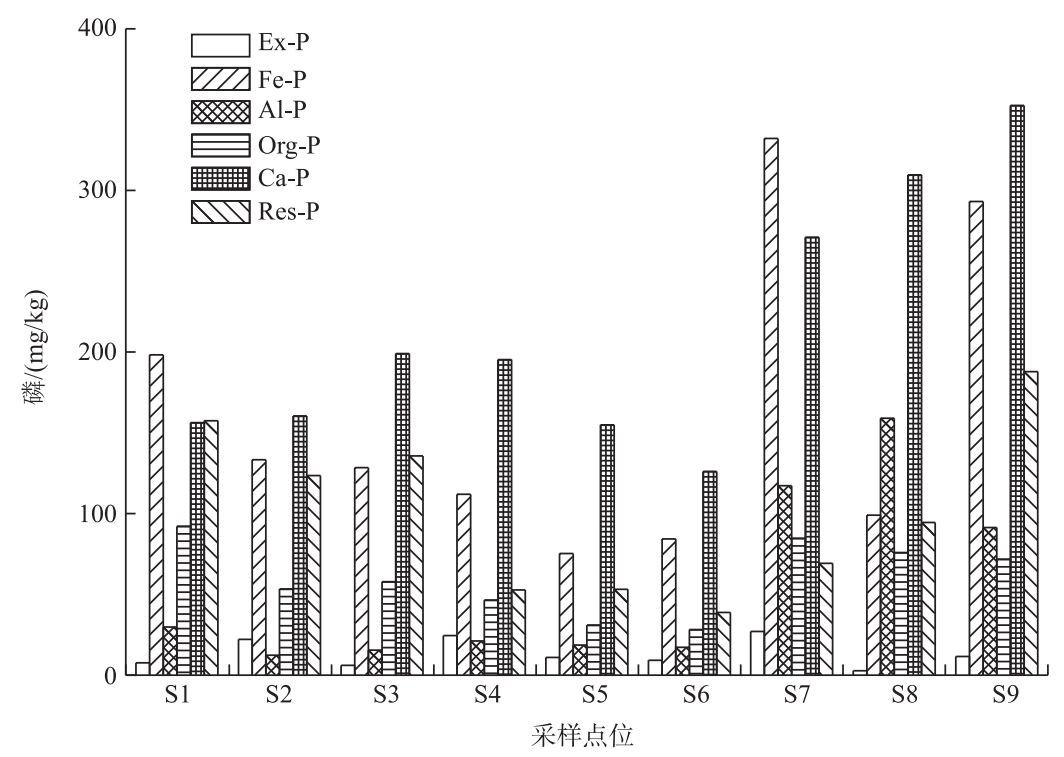

图 4 于桥水库表层沉积物中各形态磷含量及空间分布

Fig.4 Contents and spatial distribution of phosphorus forms in surface sediments from Yuqiao Reservoir

Ca-P 是一种典型的惰性磷, 与潜在活性磷有很大的不同. 首先, 它稳定存在于各种岩土矿物中, 含量随着 时间和空间的变化不大; 其次, Ca-P 含量占 TP 含量的比例很高,于桥水库沉积物中 Ca-P 所占比例为 $24 \%$ $46 \%$, 我国很多地区的水库沉积物磷形态都以 Ca-P 为主, 如丹江口水库 ${ }^{[2]}$ 、长江河口青草沙水库 ${ }^{[30]}$ 、三峡水 库 ${ }^{[18]}$ 等, Ca-P 含量有可能随着富营养化程度的加重而升高, 但是所占 TP 的比例没有明显变化; 第三, Ca-P 被普遍认为是生物难以直接利用的磷, 水生动植物、藻类、细菌等很难将其转化并合成自身营养物质; 最后, 一般的水力条件下很难释放, 只有在 $\mathrm{pH}$ 值较低的情况下才有可能释放 ${ }^{[30]}$, 然而于桥水库等大多数水库沉 积物呈弱碱性 (表 1), Ca-P 难以直接释放到上覆水中, 这对于有效降低水库富营养化程度有着积极的作用. 
于桥水库沉积物 Ca-P 的空间分布特征为由东向西逐渐递减, 人库河口处沉积物的 Ca-P 含量最高 (图 4). 造 成东、西部区域 Ca-P 含量差异较大的原因主要有两个: 一方面是水库底泥中自生钙磷含量较高, 为沉积物 早期成岩的内生过程中形成的和生物成因的钙结合态磷, 东部地势较为平坦, 进人水库的碎屑物质较多; 另 一方面是上游大黑汀水库底层水体厌氧, 调水人库的时候, 大量可溶性磷进人于桥水库, 来水的 $\mathrm{pH}$ 较低; 而 于桥水库 $\mathrm{pH}$ 高, 又是碳酸钙水体, 二者汇合之后, 于桥水库水体 $\mathrm{pH}$ 向酸性偏移, 部分固体的 $\mathrm{CaCO}_{3}$ 变成 $\mathrm{Ca}\left(\mathrm{HCO}_{3}\right)_{2}$, 钻离子浓度增加, 与可溶性磷结合的反应增强, 形成磷酸钲沉淀, 在人河口附近沉淀.

Res-P 是难溶性磷, 是最稳定的难释放态磷, 在环境条件变化情况下也很难释放, 与其他形态磷之间的 转化量很小, 若潜在活性磷转化成 Res-P 则意味着被永久固定在沉积物中, 因此 Res-P 被称为永久结合态

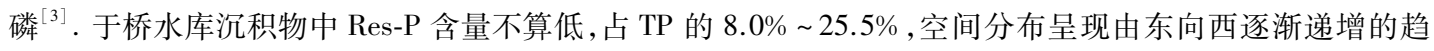
势. 于桥水库西部区域沉积物 Res-P 的相对含量比东部区域高, Al-P 和 Org-P 等潜在活性磷的相对含量则呈 相反的趋势 (图 4), 由此可以判断水库下游西部区域比水库上游黎河人库口处的水质状况更好, 这与我们对 于桥水库水质调查结果一致. 同时水库下游坝前水深较深, 大量悬浮物的絮凝、凝聚作用促使悬浮物发生自 然沉降过程, 沉积物再悬浮时间加长, 进而导致上覆水水体中磷浓度显著降低 ${ }^{[31]}$.

\section{3 沉积物磷形态的垂直分布特征}

沉积物中不同形态的磷在垂直方向的分布有很大差异, 同一形态磷在不同区域内垂直方向的分布趋势 也不一致. 本文将划分 5 个区域 (北部、南部、东部、西部和库区中心) 来研究于桥水库沉积物磷形态的垂直 分布特征(图 5).

于桥水库北部区域的代表点位为 $\mathrm{S} 2$ 和 $\mathrm{S} 4$, 各形态磷随着深度的变化呈现相似的波动趋势. 在深度 $0 \sim$ $20 \mathrm{~cm}$ 内, 各形态磷和 TP 含量随着深度增加逐渐减少, 在深度 $20 \sim 30 \mathrm{~cm}$ 内, 只有 Al-P 和 Org-P 含量随着深 度增加出现逐渐增加的趋势, 其他形态磷和 TP 含量依旧随着深度增加继续减少. 此区域沉积物中的 Ex-P 含量在 $25 \sim 30 \mathrm{~cm}$ 的最底层为 $1.3 \mathrm{mg} / \mathrm{kg}$, 与其他区域相差不大, 当深度不断增加时含量大幅度增加, 在 $0 \sim 5$ $\mathrm{cm}$ 的表层出现最高值, 为 $24.4 \mathrm{mg} / \mathrm{kg}$, 上升幅度高达 $94.6 \%$, 说明受到生活污水排放的影响很大 ${ }^{[22]}$, 生活污 水首先排放进人水库上覆水中, 磷被水中颗粒物和氧化物物理甚至化学吸附 ${ }^{[32]}$, 在沉积物表层大量累积. 该区域 Fe-P 含量与其他区域相比稍低一些, 受地形影响, 这里地势较高, 悬浮物沉降较少, Fe-P 含量低较为 正常; Fe-P 含量随深度的增加逐渐降低, 主要是因为铁的氧化物和氢氧化物与磷酸根的结合能力逐步降 低 ${ }^{[33]}$; 深度越深, 有机质降解促使环境中溶解氧含量越低, 沉积物还原能力越强, 由于 Fe-P 是可还原态磷, 对氧化还原电位很敏感, $\mathrm{Fe}^{3+}$ 向 $\mathrm{Fe}^{2+}$ 转化, 因此不溶性的 $\mathrm{Fe}(\mathrm{OH})_{3}$ 变成可溶性的 $\mathrm{Fe}(\mathrm{OH})_{2}$, 吸附在沉积物中 的磷随着 $\mathrm{Fe}^{2+}$ 的溶解迁移进人间隙水 ${ }^{[34]}$, 最后依靠浓度梯度的扩散作用释放进人上覆水, 从而导致 Fe-P 含 量随着深度增加逐渐降低. Al-P 和 Org-P 虽然与 Fe-P 同为潜在活性磷, 但在垂直分布上有所不同, Al-P 和 Org-P 含量随深度的增加出现先降低后增加的趋势, 在深度为 $15 \sim 20 \mathrm{~cm}$ 处发生转折, 在最底层沉积物中的 含量甚至超过了表层. Al-P 和 Org-P 含量在沉积物中较为稳定, 常用来评估生物有效磷的含量 ${ }^{[35-36]}$, 深度越 深, 蓝藻和植物等生物沉积越少, Al-P 和颗粒态有机磷的矿化作用和植物的吸收作用越来越弱, 使得其无法 溶解进人间隙水, 累积在底层沉积物中; 还有可能是因为此区域水草生长旺盛, 表层的生物可利用磷被水草 根系利用, 导致 Al-P 和 Org-P 含量在表层比底层更低.

表 3 放射性核素 $\left({ }^{210} \mathrm{~Pb}\right.$ 和 $\left.{ }^{137} \mathrm{Cs}\right)$ 计算的沉积年代

Tab.3 Deposition age of radionuclide calculations

$$
\left({ }^{210} \mathrm{~Pb} \text { and }{ }^{137} \mathrm{Cs}\right)
$$

\begin{tabular}{cc}
\hline 沉积深度 $/ \mathrm{cm}$ & 时间 \\
\hline $0 \sim 5$ & $2016-2005$ 年 \\
$5 \sim 10$ & $2005-1994$ 年 \\
$10 \sim 15$ & $1994-1983$ 年 \\
$15 \sim 20$ & $1983-1972$ 年 \\
$20 \sim 25$ & $1972-1960$ 年 \\
\hline
\end{tabular}

于桥水库南部区域的代表点位为 $\mathrm{S} 3$ 和 $\mathrm{S} 6$, 这两个 点位的各形态磷含量在垂直方向上有较为复杂的分布 规律, 各形态磷随深度的变化有不同的趋势, 尤其是 S6 点位, 磷含量在各个深度差异不大, 结合放射性核素 $\left({ }^{210} \mathrm{~Pb}\right.$ 和 $\left.{ }^{137} \mathrm{Cs}\right)$ 计算的沉积年代来分析污染分布特征, 如 表 3 所示. 从沉积深度可以看出于桥水库沉积物各磷形 态的历史变化, S6 点位 Fe-P、Al-P 和 Org-P 3 大潜在活 性磷在表层至最底层的含量分别为 $62.2 \sim 87.2 、 15.5 \sim$ 18.6 和 $15.6 \sim 34.1 \mathrm{mg} / \mathrm{kg}$, 相邻两层之间的磷含量仅在很 小的范围内波动, 可以表明从 1960s 开始此区域就已经 

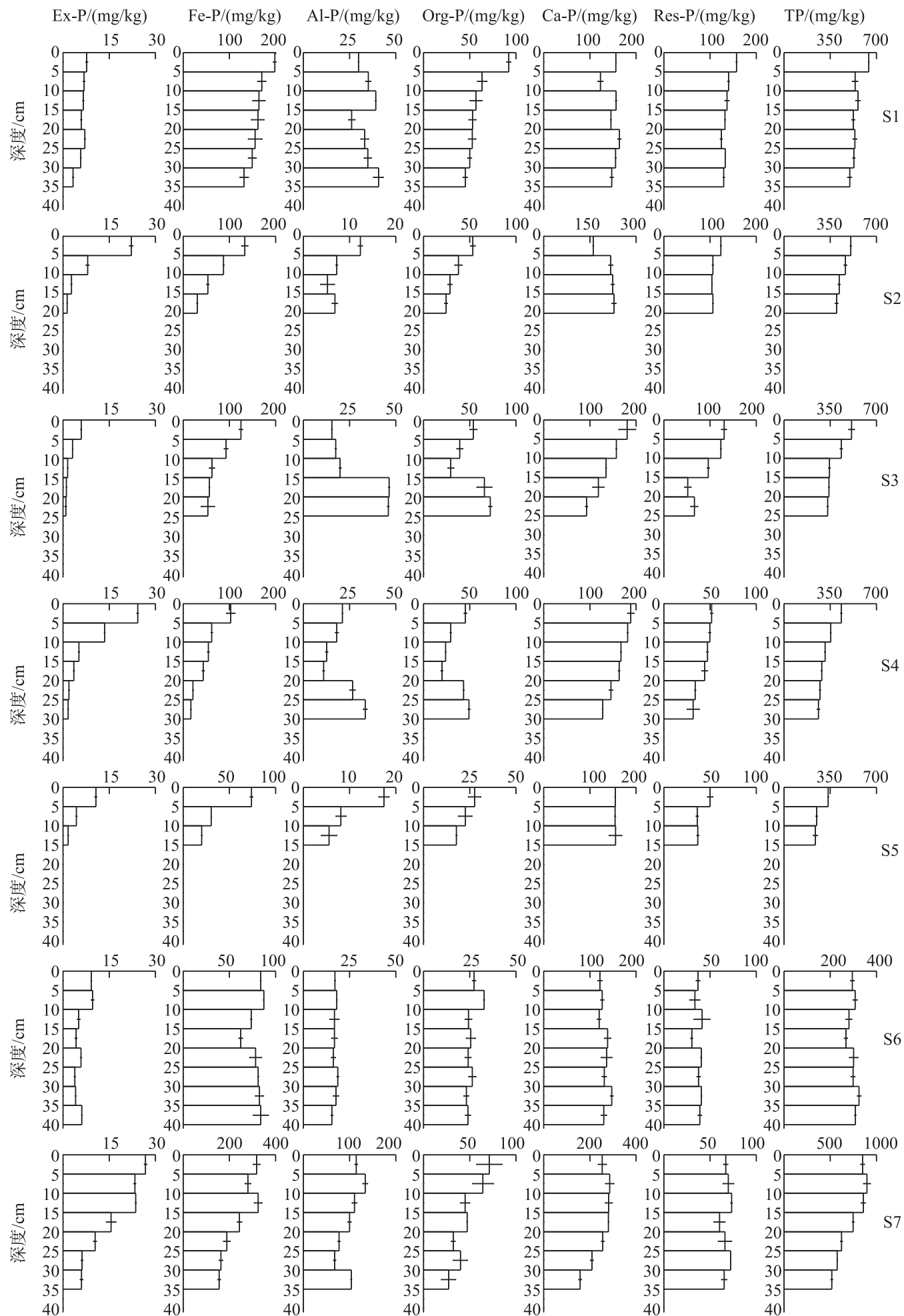

图 5 于桥水库沉积物中各形态磷含量及垂直分布

Fig.5 Contents and vertical distribution of phosphorus forms in sediments from Yuqiao Reservoir 
受到比较严重的磷污染 ${ }^{[37]}$, 至今为止也无较大的改变, 造成这种情况的主要原因是于桥水库南面为翠屏山, 几年前原本坐落着别山镇的几百户村庄, 在 S6 点位附近有一条古老的河道, 这里的耕种和灌溉方式较为原 始, 村民生活非常依赖农业的发展, 外源磷主要来自农业面源污染, 同时南面的翠屏山山谷之中有许多涧溪 流过, 人为因素造成的污染顺着地势向于桥水库扩散, 此区域的污染可以说是一个历史遗留问题, 因此政府 部门为了保护水源地的污染情况不再进一步恶化,最近两年开始组织大批村民搬离水库周边区域.

于桥水库东部区域的代表点位为 $\mathrm{S} 7$, 位于水库上游、黎河下游, $\mathrm{TP}$ 含量最高, 是水库中心区域同一深度 的 $2.5 \sim 3.6$ 倍, 是高磷区域. 在垂直方向上的分布特征为表层总体高于底层, 黎河河水的冲刷所带来的磷会 随着时间不断改变, 各形态磷和 TP 含量的范围也比其他区域更宽, 说明黎河河水含磷量的多少直接影响了 沉积物中的磷含量, 黎河河水带来的外源磷对于桥水库总体的污染状况起决定性作用 ${ }^{[38]}$. Ex-P、Fe-P、Al-P 和 Org-P 等活性磷在表层富集, 随着深度增加逐渐降低, 15 20 cm 深度到 $10 \sim 15 \mathrm{~cm}$ 深度有最大上升幅度, 表明从 1980s 开始磷的沉积量迅速增加, 与日益增强的工农业发展导致的污染问题息息相关. 此区域位于淋 河和黎河的人库河口, 水流快、水深浅、船只多、风浪大, 水动力扰动作用较大, 容易发生沉积物再悬浮过 程 ${ }^{[31]}$, 内源性磷的释放量加大, 导致上覆水水质变差, 藻类能利用这些活性磷满足自身生命活动, 造成水体 $\mathrm{pH}$ 值升高和季节性缺氧, 导致沉积物中活性磷的释放, 这种结果反而又使藻类大量繁殖, 最终发生水华.

于桥水库西部区域的代表点位为 S1, 位于水库下游、大坝上游, 西面为蓟县城区. 原本黎河带人的外源 性磷进人水库后会被稀释, 从上游到下游磷含量会逐步降低, 但是由于水库下游建有拦河大坝, 再加上坝前 区域水深是其他区域的近两倍, 因此坝前区域好比是一个颗粒物捕获器, 颗粒物会在此区域大量沉降, 蓝藻 及碎屑堆积导致磷在此处停留并沉降, 于是 Org-P 在表层大量咜存, 并随深度逐渐降低; 主要原因是随着深 度增加含氧量降低, 活性有机磷被大量矿化为无机磷释放到间隙水 ${ }^{[39]}$, 另外植物根部的磷酸酶活性增 强 ${ }^{[40]}$, 活性有机磷被微生物吸收、发生矿化作用, 同时深层沉积物处于厌氧状态, 活性有机磷被矿化为其他 各种无机溶解态, 从而进人间隙水中, 扩散作用导致溶解态磷从高浓度向低浓度的方向迁移, 因此在垂直方 向上表现为随深度的增加逐渐降低. 此区域的 Res-P 为整个于桥水库的最高值, Res-P 是最难释放、最稳定 的, 是在较长时间尺度上形成的, 从内因上来说与早期成岩过程中生成的矿物质有关, 从外因上来说是由于 聚磷菌在好氧或缺氧的条件下能够摄取外部环境中的磷酸盐, 形成多聚磷酸盐穴存在细胞体内, 因此将水 体中溶解性磷转化成颗粒态磷, 稳定固化在沉积物中 ${ }^{[41]}$.

于桥水库中心区域的代表点位为 $\mathrm{S} 5$, 距离岸边较远, 受到风力、水动力、河流、生活污水和工业废水等外 界环境的影响较小, TP 含量是最低的. 各形态磷和 TP 含量都随着深度增加逐渐降低, 尤其是活性磷的降低 很明显, Ex-P、Fe-P、Al-P 和 Org-P 含量在表层到最底层的下降幅度分别为 $84.3 \% 、 72.8 \% 、 68.0 \%$ 和 $35.8 \%$,于 桥水库在早期的演变过程中水体生产力低, 有机质的累积量少, 底层的磷含量较低, 近两年, 部分区域进人 富营养化, 外源性磷大量输人, 藻类过快增殖, 沉积物吸附并沉积越来越多的磷 ${ }^{[42-43]}$, 造成了表层富集的现 象, 说明现阶段此区域的磷以滞留为主、释放潜力较小.

\section{3 结论}

1) 于桥水库表层沉积物 TP 含量为 $303.7 ~ 997.8 \mathrm{mg} / \mathrm{kg}$, 属于中轻度污染水平. 水库东部黎河人库河口 为水库最高含磷区域, 生物可利用磷及释放风险较高. 于桥水库沉积物各形态磷质量分数大小顺序依次为: Ca-P $>$ Fe-P $>$ Res-P $>$ Al-P $>$ Org-P $>$ Ex-P.

2) 于桥水库中心区域的水柱 TP 浓度均小于周围点位, 说明上覆水 TP 浓度的增加主要受到外源性输人 的影响. 上覆水 $\mathrm{TP}$ 浓度最高值主要集中在坝前区域 ( S1 点位) 以及水库北部区域 ( S2 和 S4 点位), 因此在 所有外源性输人中, 人类活动是于桥水库上覆水体中 $\mathrm{TP}$ 浓度升高的重要原因.

3) 于桥水库磷形态空间分布特征: Ex-P 含量由南至北逐渐递增, 这与库区北岸居住大量的人口有关; Fe-P、Al-P 和 Ca-P 含量由东至西逐渐递减, 主要受到黎河河水夹带的外源性磷输人的影响; Org-P 含量在水 库上游和下游较高, 与调水及人库河流水质及农业面源污染有关; Res-P 含量由东至西逐渐递增, 与活性磷 的分布规律相反.

4) 于桥水库磷形态垂直分布特征: 北部区域在垂直方向上的波动比较统一, 各形态磷和 TP 含量随着深 
度增加逐渐减少; 南部区域底层与表层沉积物相差不大, 表明从 $1960 \mathrm{~s}$ 开始便受到比较严重的磷污染, 是一 个历史遗留问题; 东部区域各形态磷含量总体表现为表层比底层高, 活性磷含量很高, 且在表层富集, 具有 很高的释磷风险; 西部区域沉积物中 Org-P 含量较高, 随深度的增加有明显降低的趋势. 中心区域的各形态 磷和 TP 含量几乎均为最低, 且随着深度增加逐渐降低, 现阶段沉积物中的磷以滞留为主, 释放潜力较小. 致谢: 本文的研究工作得到了天津市水务局引滦工程于桥水库管理处及天津市水利科学研究院的大力协 助, 在此深表谢意!

\section{4 参考文献}

[ 1 ] Pei G, Wang Q, Liu G. The role of periphyton in phosphorus retention in shallow lakes with different trophic status, China. Aquatic Botany, 2015, 125: 17-22.

[ 2 ] Wang WW, Wang SH, Zhao L et al. Identification of inorganic and organic species of phosphorus and its bio-availability by aequential extraction method in surface sediments of Danjiangkou Reservoir. China Environmental Science, 2016, 36(3): 808-818. [王雯雯, 王书航, 赵丽等. 丹江口水库表层沉积物有机/无机磷形态特征. 中国环境科学, 2016, 36(3): 808-818.]

[ 3 ] He J, Chen CY, Deng WM et al. Distribution and release characteristics of phosphorus in wate-sediment interface of Lake Dianchi. J Lake Sci, 2015, 27(5) : 799-810. DOI:10.18307/2015.0506. [何佳, 陈春瑜, 邓伟明等. 滇池水-沉积物 界面磷形态分布及潜在释放特征. 湖泊科学, 2015, 27(5) : 799-810.]

[ 4 ] Ruttenberg KC. Development of a sequential extraction method for different forms of phosphorus in marine-sediment. Limnology and Oceanography, 1992, 37(7) : 1460-1482.

[ 5 ] Huang QH, Wang DH, Wang CX et al. Vertical variation of the phosphorus form in the sediments of Meiliang Bay and Wuli Lake of Taihu Lake. China Environmental Science, 2004, 24(2): 20-23. [ 黄清辉, 王东红, 王春霞等. 太湖梅梁 湾和五里湖沉积物磷形态的垂向变化. 中国环境科学, 2004, 24(2) : 20-23.]

[ 6 ] Cheng D, Liu X, Wang L et al. Seasonal variation and sediment-water exchange of antibiotics in a shallower large lake in North China. Science of the Total Environment, 2014, 476/477: 266-275.

[ 7 ] Baker DB, Confesor R, Ewing DE et al. Phosphorus loading to Lake Erie from the Maumee, Sandusky and Cuyahoga rivers: The importance of bioavailability. Journal of Great Lakes Research, 2014, 40(3) : 502-517.

[ 8 ] Wang C, Liu J, Pei Y. Effect of hydrogen sulfide on phosphoruslability in lake sediments amended with drinking water treatment residuals. Chemosphere, 2013, 91(9): 1344-1348.

[ 9 ] Zhang C, Liu HA, Gao XP et al. Potential impacts of climate change on phosphorus and DO in Yuqiao Reservoir. Environmental Science, 2016, 37(8): 2932-2939. [张晨, 刘汉安, 高学平等. 气候变化对于桥水库总磷与溶解氧的潜在影 响分析. 环境科学, 2016, 37(8): 2932-2939.]

[10] Wu D, Wang HY, Zhang Z et al. Investigation of summer plankton community structure in Yuqiao Reservoir, Tianjin. $J$ Lake Sci, 2013, 25(5): 735-742. DOI:10.18307/2013.0516. [武丹, 王海英, 张震. 天津于桥水库夏季浮游生物调 查及群落结构变化. 湖泊科学, 2013, 25(5): 735-742.]

[11] Zheng WK, Liu XB, Zhao XG et al. Phytoplankton community feature in Yuqiao Reservoir. Environmental Monitoring in China, 2015, 31(1) : 35-40. [郑吴柯, 刘宪斌, 赵兴贵等. 于桥水库浮游植物群落特征. 中国环境监测, 2015,31 (1) : 35-40.]

[12] "Water and wastewater monitoring and analysis method" editorial board of State Environmental Protection Administration of China ed. Monitoring and analysis methods of water and wastewater: fourth edition. Beijing: China Environmental Science Press, 2002. [ 国家环境保护总局《水和废水监测分析方法》编委会. 水和废水监测分析方法: 第 4 版. 北京: 中国 环境科学出版社, 2002.]

[13] Kaiserli A, Voutsa D, Samara C. Phosphorus fractionation in lake sediments-Lakes Volvi and Koronia, N. Greece. Chemosphere, 2002, 46(8): 1147-1155.

[14] Barrow NJ. A mechanistic model for describing the sorption and desorption of phosphate by soil. Journal of Soil Science, 1983, 34(4) : 733-750.

[15] Persaud D, Jaagumagi R, Hayton A eds. Guidelines for the protection and management of aquatic sediment quality in Ontario: Report. Water Resources Branch, Ontario Ministry of the Environment, 1993. 
[16] Xu JQ. Research on vertical distribution of phosphorus forms in the sediment of Taihu Lake [Dissertation]. Nanjing: Nanjing University of Science \& Technolongy, 2010. [徐景琪. 太湖沉积物磷形态的空间分布研究 [学位论文]. 南京: 南 京理工大学, 2010.]

[17] Chen CY, Xu XM, Deng WM et al. Characteristics of phosphorus adsorption on surface sediments of Dianchi Lake. Acta Scientiae Circumstantiae, 2014, 34(12):3065-3075. [陈春瑜, 徐晓梅, 邓伟明等. 滇池表层沉积物对磷的吸附特 征. 环境科学学报, 2014, 34(12): 3065-3075.]

[18] Zhang B, Fang F, Guo J et al. Phosphorus fractions and phosphate sorption-release characteristics relevant to the soil composition of water-level-fluctuating zone of Three Gorges Reservoir. Ecological Engineering, 2012, 40: 153-159.

[19] Carling GT, Richards DC, Hoven H et al. Relationships of surface water, pore water, and sediment chemistry in wetlands adjacent to Great Salt Lake, Utah, and potential impacts on plant community health. Science of the Total Environment, 2013, 443: 798-811.

[20] Yuan HZ, Shen J, Liu EF. Analysis of phosphorus forms in different regions of Taihu Lake. China Environmental Science, 2010, 30(11) : 1522-1528. [袁和忠, 沈吉, 刘恩峰. 太湖不同湖区沉积物磷形态变化分析. 中国环境科学, 2010, 30(11): 1522-1528.]

[21] Xiang SL, Zhou WB. Phosphorus existing forms and distribution characteristic in Lake Poyang sediments. J Lake Sci, 2010, 22(5) : 649-654. DOI: 10.18307/2010.0504. [ 向速林, 周文斌. 鄱阳湖沉积物中磷的赋存形态及分布特征. 湖泊科学, 2010, 22(5): 649-654.]

[22] Chen HL, Yuan XY, Wang H et al. Distributions of phosphorus fractions in suspended sediments and surface sediments of Tiaoxi mainstreams and cause analysis. Environmental Science, 2015, 36(2): 464-470. [陈海龙, 袁旭音, 王欢等. 苕 溪干流悬浮物和沉积物的磷形态分布及成因分析. 环境科学, 2015, 36(2) : 464-470.]

[23] Wang SR, Jin XC, Zhao HC et al. Phosphorus fractions and its release in the sediments from the shallow lakes in the middle and lower reaches of Yangtze River area in China. Colloids and Surfaces A: Physicochemical and Engineering Aspects, 2006, 273(1/2/3): 109-116.

[24] Petticrew EL, Arocena JM. Evaluation of iron-phosphate as a source of internal lake phosphorus loadings. Science of the total Environment, 2001, 266(1): 87-93.

[25] Zhang J, Huang X. Relative importance of solid-phase phosphorus and iron on the sorption behavior of sediments. Environmental Science \& Technology, 2007, 41(8) : 2789-2795.

[26] Wang S, Jin X, Bu Q et al. Evaluation of phosphorus bioavailability in sediments of the shallow lakes in the middle and lower reaches of the Yangtze River region, China. Environmental Earth Sciences, 2010, 60(7) : 1491-1498.

[27] Zhou Q, Gibson CE, Zhu YM. Evaluation of phosphorus bioavailability in sediments of three contrasting lakes in China and the UK. Chemosphere, 2001, 42(2): 221-225.

[28] Chen J, Lu S, Zhao Y et al. Effects of overlying water aeration on phosphorus fractions and alkaline phosphatase activity in surface sediment. Journal of Environmental Science, 2011, 23(2) : 206-211.

[29] Rydin E. Potentially mobile phosphorus in Lake Erken sediment. Water Research, 2000, 34(7) : 2037-2042.

[30] Jin XD, Wu H, Chen ZM et al. Phosphorus fractions, sorption characteristics and its release in the sediments of Yangtze Estuary Resevoir, China. Environmental Science, 2015, 36(2): 448-456. [ 金晓丹, 吴吴, 陈志明等. 长江河口水库沉 积物磷形态、吸附和释放特性. 环境科学, 2015, 36(2): 448-456.]

[31] Huang L, Fang H, Fazeli M et al. Mobility of phosphorus induced by sediment resuspension in the Three Gorges Reservoir by flume experiment. Chemosphere, 2015, 134: 374-379.

[32] Tang X, Wu M, Dai X et al. Phosphorus storage dynamics and adsorption characteristics for sediment from a drinking water source reservoir and its relation with sediment compositions. Ecological Engineering, 2014, 64: 276-284.

[33] Song YY, Feng MH, Su ZG et al. Vertical distribution of chemical speciation of phosphorus in sediments from different sources of Fuxian Lake. Acta Scientiae Circumstantiae, 2013, 33(9): 2579-2589. [ 宋媛媛, 冯慕华, 苏争光等. 抚仙湖 不同来源沉积物磷形态垂向分布特征. 环境科学学报, 2013, 33(9): 2579-2589. ]

[34] Jing L, Liu X, Bai S et al. Effects of sediment dredging on internal phosphorus: A comparative field study focused on iron and phosphorus forms in sediments. Ecological Engineering, 2015, 82: 267-271.

[35] Xiong Q, Jiao LX, Wang SR et al. Characteristics and bioavailability of organic phosphorus from different sources of sediments in Dianchi Lake. Environmental Science, 2014, 35(11): 4118-4126. [熊强, 焦立新, 王圣瑞等. 滇池沉积物有 
机磷垂直分布特征及其生物有效性. 环境科学, 2014, 35(11)：4118-4126. ]

[36] Monbet P, Mckelvie ID, Worsfold PJ. Dissolved organic phosphorus speciation in the waters of the Tamar estuary ( SW England). Geochimica et Cosmochimica Acta, 2009, 73(4): 1027-1038.

[37] Ni Z, Wang S. Historical accumulation and environmental risk of nitrogen and phosphorus in sediments of Erhai Lake, Southwest China. Ecological Engineering, 2015, 79: 42-53.

[38 ] Shiyue C, Yingying C, Jiazhen L et al. Vertical Variation of Phosphorus Forms in Core Sediments from Dongping Lake, China. Procedia Environmental Sciences, 2011, 10: 1797-1801.

[39] Khoshmanesh A, Hart BT, Duncan A et al. Luxury uptake of phosphorus by sediment bacteria. Water Research, 2002,36 (3) : 774-778.

[40] Tarafdar JC, Jungk A. Phosphatase activity in the rhizosphere and its relation to the depletion of soil organic phosphorus. Biology and Fertility of Soils, 1987, 3(4) : 199-204.

[41] Khoshmanesh A, Hart BT, Duncan A et al. Biotic uptake and release of phosphorus by a wetland sediment. Environmental Technology, 1999, 20(1): 85-91.

[42] Zhang S, An W, Li X. Research on phosphorus loads and characteristics of adsorption and release in surface sediments of Nanyang Lake and Weishan Lake in China. Environmental Monitoring and Assessment, 2015, 187(1) : 1-7.

[43] Borling K, Otabbong E, Barberis E. Phosphorus sorption in relation to soil properties in some cultivated Swedish soils. Nutrient Cycling in Agroecosystems, 2001, 59(1): 39-46. 